\title{
Effect of Medium Composition on in vitro Seed Germination and Plant Development in Kentucky Bluegrass (Poa pratensis L. cv. Evora)
}

\author{
Arda ACEMI
}

Kocaeli University, Faculty of Arts and Sciences, Department of Biology, İzmit, Kocaeli, Turkey ORCID ID: Arda ACEMI: https://orcid.org/0000-0003-0270-8507

\begin{abstract}
Received: 18.11 .2020
Accepted: 12.01 .2021

Published online: 31.03 .2021

Issue published: 30.06 .2021

Abstract: In the current study, the effects of De Greef \& Jacobs (DG), Linsmaier \& Skoog (LS), Murashige \& Skoog (MS), and Schenk \& Hildebrandt (SH) media were tested on seed germination and plant development in Poa pratensis cv. Evora. The highest germination rate $(83 \pm 2.74 \%)$ was found on SH medium, whereas LS medium gave the lowest $(46 \pm 4.18 \%)$ germination rate. The statistically same leaf numbers were recorded from SH $(2.10 \pm 0.27)$ and DG $(2.12 \pm 0.18)$ media. SH and DG media gave $4.28 \pm 0.28 \mathrm{~cm}$ and $4.16 \pm 0.31 \mathrm{~cm}$ mean leaf lengths, respectively. SH medium gave the maximum mean root number (3.09 \pm 0.26$)$. However, the LS medium gave the lowest mean root number $(1.84 \pm 0.10)$. The longest roots $(1.43 \pm 0.19 \mathrm{~cm})$ were observed in the plants grown in SH medium. However, DG medium had the minimum mean root length $(0.81 \pm 0.08 \mathrm{~cm})$. In conclusion, $\mathrm{SH}$ medium should be preferred over the other medium tested in in vitro tissue culture studies on the species to increase the biomass production yield. The efficacy of SH medium in the in vitro propagation of $P$. pratensis could be increased using growth promoters.
\end{abstract}

Keywords: Macroelements; microelements; tissue culture; turfgrass; vitamins.

\section{Besiyeri Bileşiminin Çayır Salkımotunda (Poa pratensis L. cv. Evora) in vitro Tohum Çimlenmesi ve Bitki Gelişimi Üzerindeki Etkisi}

\begin{abstract}
Öz: Bu çalışmada, Poa pratensis cv. Evora'da De Greef \& Jacobs (DG), Linsmaier \& Skoog (LS), Murashige \& Skoog (MS) ve Schenk \& Hildebrandt (SH) besiyerlerinin tohum çimlenmesi ve bitki gelişimi üzerindeki etkileri test edilmiştir. En yüksek

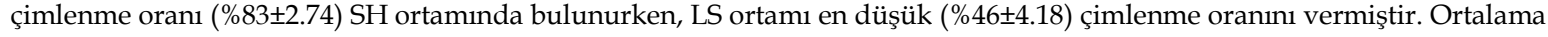
yaprak sayıları SH $(2.10 \pm 0.27)$ ve DG $(2.12 \pm 0.18)$ ortamlarından istatistiksel olarak aynı kaydedilmiştir. Ortalama yaprak uzunlukları SH ve DG ortamlarında sırasıyla $4.28 \pm 0.28 \mathrm{~cm}$ ve $4.16 \pm 0.31 \mathrm{~cm}$ olarak ölçülmüştür. Maksimum ortalama kök sayısı (3.09 \pm 0.26$)$ SH ortamından elde edilmiştir. Bununla birlikte, en düşük ortalama kök sayısı $(1.84 \pm 0.10)$ LS ortamında kaydedilmiştir. En uzun kökler $(1.43 \pm 0.19 \mathrm{~cm}) \mathrm{SH}$ ortamında yetiştirilen bitkilerde gözlenmiştir. Bununla birlikte, DG ortamı minimum ortalama kök uzunluğunu $(0.81 \pm 0.08 \mathrm{~cm})$ vermiştir. Sonuç olarak, biyokütle üretimini artırmak için bu tür üzerinde yapılan in vitro doku kültürü çalışmalarında test edilen diğer besiyerlerine kıyasla SH besiyeri tercih edilmelidir. SH ortamının P. pratensis'in in vitro gelişimindeki etkinliği büyüme destekleyicileri kullanılarak artırılabilir.
\end{abstract}

Anahtar kelimeler: Makroelementler; mikroelementler; doku kültürü; çim; vitaminler.

\section{Introduction}

Kentucky bluegrass (Poa pratensis L.) is a perennial and dense turf-producing cool-season grass, which is generally used after getting mixed with perennial ryegrass (Lolium perenne L.) to obtain a more stabilized soil and diseaseresistant turf with better color and quality (Walker et al., 2007). The species is native to Europe and Asia but has been cultivated for sports and ornamental use in many regions with a temperate climate (Casler, 2006). It grows well on limestone-originated, medium-textured, and welldrained soils. However, it can adapt to poorly-drained and heavy-textured soils. The species can also tolerate severe droughts; although, it prefers humid areas with temperatures between 15 and $32^{\circ} \mathrm{C}$ (Bush, 2002). These advantages of $P$. pratensis make it an attractive option among other grass species used for forage and lawn production. Like other turfgrasses, the primary propagation method of $P$. pratensis is seed sowing since the vegetative propagation from rhizomes is labor-intensive for such plants.
Plant tissue culture is primarily used to process in vitro plant material utilizing meristems and organs that can be differentiated under controlled environmental conditions. The technique is used alongside other plant biotechnology applications such as molecular breeding and disease-resistant plants' production through genetic engineering applications. The optimization of tissue culture medium for in vitro plant development plays a significant role in forage and turfgrass biotechnology (Esmaeili et al., 2018). Components in tissue culture media have a vital function in the germination of plant seeds. Every plant tissue culture medium has specific formulations consisted of macro- and microelements, vitamins, and other components such as amino acids at different ratios (Acemi et al., 2018). The success of the in vitro propagation study is highly dependent on tissue culture medium composition. Therefore, different medium compositions should be tested to select the most favorable culture medium that meets the plant's macroand microelement requirements in in vitro culture. The seeds' poor germination, the comparatively modest 
growth rate of the seedlings, and the lowest yield of $P$. pratensis among other $P$ oa species pose difficulties in the turf establishment using the species (Giolo et al., 2017; Akdeniz et al., 2018). Thus, this study aims to determine the plant's requirements for its efficient seed germination and development. In addition, a better understanding of the plant's developmental physiology is provided by exploring the optimum in vitro seed germination medium for P. pratensis.

\section{Material and Methods}

\subsection{Seed source and disinfection}

The seeds of commercially available $P$. pratensis $\mathrm{L}$. cv. Evora (DLF Seeds Ltd., Denmark) were supplied by a local dealer (Sekoya Tohumculuk Ziraat San. \& Tic. A. Ş.) in Turkey and kept in a dry and dark place. Seeds' disinfection and sowing were performed in a laminar flow cabinet. One hundred seeds were placed into pouches $(4 \times 4$ $\mathrm{cm})$ made from filter papers and were disinfected by gently shaking for $8 \mathrm{~min}$ in $1 \%(\mathrm{w} / \mathrm{v})$ sodium hypochlorite $(\mathrm{NaOCl})$ solution. The $\mathrm{NaOCl}$ residues on the seeds were removed by soaking the pouch into sterile distilled water several times. The pouch with seeds was then placed onto a sterile platform made of filter papers to take excess water on the seeds.

\subsection{Media preparation, seeds' sowing, and culture conditions}

Four culture media with different formulations were employed to test their effects on seeds' germination and development of the species. The media described by De Greef \& Jacobs (1979) (DG), Linsmaier \& Skoog (1965) (LS), Murashige \& Skoog (1962) (MS), and Schenk \& Hildebrandt (1972) (SH) were prepared and supplemented with $30 \mathrm{~g} \mathrm{~L}^{-1}$ sucrose and $7 \mathrm{~g} \mathrm{~L}^{-1}$ agar and their $\mathrm{pH}$ was set to 5.7 using $1 \mathrm{~N} \mathrm{NaOH}$ or $1 \mathrm{~N} \mathrm{HCl}$ before autoclaving at $121^{\circ} \mathrm{C}$ under a pressure of $118 \mathrm{kPa}$ for $20 \mathrm{~min}$. The media formulations are given in Table 1 . The paper pouches were opened with a sterile blade and forceps and the disinfected seeds were then sown onto the media. The cultures were incubated in a plant growth chamber with a 16-h photoperiod at $23 \pm 1^{\circ} \mathrm{C}$ and under the illumination of 60 $\mu \mathrm{mol} \mathrm{m} \mathrm{m}^{-2} \mathrm{~s}^{-1}$ photosynthetic photon flux density.

Table 1. Comparison of the compositions of the culture media tested on in vitro development of P. pratensis.

\begin{tabular}{|c|c|c|c|c|}
\hline \multirow{2}{*}{$\begin{array}{l}\text { Content } \\
\text { Macroelements } \\
\end{array}$} & \multicolumn{4}{|c|}{ Quantity in medium (mg L-1) } \\
\hline & DG & LS & MS & SH \\
\hline $\mathrm{CaCl}_{2}$ & 226.50 & 332.02 & 332.02 & 151.00 \\
\hline $\mathrm{KNO}_{3}$ & 2000.00 & 1900.00 & 1900.00 & 2500.00 \\
\hline $\mathrm{MgSO}_{4}$ & 244.33 & 180.54 & 180.54 & 195.05 \\
\hline $\mathrm{NaH}_{2} \mathrm{PO}_{4}$ & 250.00 & & & \\
\hline $\mathrm{KH}_{2} \mathrm{PO}_{4}$ & & 170.00 & 170.00 & \\
\hline$\left(\mathrm{NH}_{4}\right) \mathrm{H}_{2} \mathrm{PO}_{4}$ & & & & 300.00 \\
\hline$\left(\mathrm{NH}_{4}\right)_{2} \mathrm{SO}_{4}$ & 400.00 & & & \\
\hline $\mathrm{NH}_{4} \mathrm{NO}_{3}$ & & 1650.00 & 1650.00 & \\
\hline $\mathrm{KCl}$ & 600.00 & & & \\
\hline \multicolumn{5}{|l|}{ Microelements } \\
\hline $\mathrm{CoCl}_{2} \cdot 6 \mathrm{H}_{2} \mathrm{O}$ & 0.0025 & 0.025 & 0.025 & 0.10 \\
\hline $\mathrm{CuSO}_{4} .5 \mathrm{H}_{2} \mathrm{O}$ & 0.0025 & 0.025 & 0.025 & 0.20 \\
\hline FeNaEDTA & 36.7 & 36.7 & 36.7 & 19.8 \\
\hline $\mathrm{H}_{3} \mathrm{BO}_{3}$ & 10.62 & 6.2 & 6.2 & 5.00 \\
\hline KI & 1.58 & 0.83 & 0.83 & 1.00 \\
\hline $\mathrm{MnSO}_{4} \cdot \mathrm{H}_{2} \mathrm{O}$ & 1.68 & 16.9 & 16.9 & 10.00 \\
\hline $\mathrm{Na}_{2} \mathrm{MoO}_{4} \cdot 2 \mathrm{H}_{2} \mathrm{O}$ & 0.0025 & 0.25 & 0.25 & 0.10 \\
\hline $\mathrm{ZnSO}_{4} .7 \mathrm{H}_{2} \mathrm{O}$ & 1.06 & 8.6 & 8.6 & 1.00 \\
\hline \multicolumn{5}{|l|}{ Vitamins } \\
\hline myo-inositol & 100.0 & 100.0 & 100.0 & 1000.0 \\
\hline Nicotinic acid & 1.0 & & 0.5 & 5.0 \\
\hline Pyridoxine $\mathrm{HCl}$ & 1.0 & & 0.5 & 0.5 \\
\hline Thiamine $\mathrm{HCl}$ & 10.0 & 0.4 & 0.1 & 5.0 \\
\hline \multicolumn{5}{|l|}{ Amino acids } \\
\hline Glycine & & & 2.0 & \\
\hline
\end{tabular}

\subsection{Data collection and statistical analysis}

One hundred seeds (20 seeds per vessel) were sown onto each medium. Each repeat consisted of one culture vessel. The number of germinated seeds and mean leaf and root numbers and lengths were calculated at the end of the incubation period of $30 \mathrm{~d}$. Data were given as mean \pm standard deviation (SD). Means were compared using Duncan's multiple range test at a significance level of $\mathrm{P}<0.05$. IBM SPSS Statistics 22 software was used for statistical analysis. The data were normalized to 0-1 interval and hierarchical clustering analysis was performed according to the Euclidean distance and unweighted pair group method with arithmetic mean (UPGMA). BioVinci data visualization software, version 1.1.5, was used to create the clustering heatmap.

\section{Results and Discussion}

The general appearances of the cultures at the end of the incubation period are given in Figure 1. The percentage of germinated seeds greatly varied among the media tested (Fig. 2). SH medium had the highest $(83 \pm 2.74 \%)$ germination percentage, whereas the seeds cultured on LS medium had the lowest $(46 \pm 4.18 \%)$ germination rate. The results showed that the $\mathrm{SH}$ medium gave $80 \%, 30 \%$, and $22 \%$ higher germination rates than LS, MS, and DG media, respectively. Statistically, the same germination rates were found from MS and DG media. Seed germination in many species is affected by soil's chemical and physical properties and by several environmental conditions in nature (Borawska-Jarmułowicz et al., 2017; Benvenuti \& Mazzoncini, 2018). However, environmental conditions 
such as light intensity, photoperiod, temperature, and relative humidity remain stable in tissue culture studies allowing researchers to test the effects of culture medium composition, simulating soil's chemical components. Therefore, culture medium components such as macroand microelements and supplements such as plant growth regulators are decisive in seed germination success in such studies (Acemi \& Özen, 2019). The current study is solely based on testing the effects of medium compositions that means the differences in all developmental parameters are culture medium-specific. Therefore, the highest germination rate obtained from $\mathrm{SH}$ medium might be attributed to its rich $\mathrm{KNO}_{3}, \mathrm{PO}_{4}$, and vitamin content since the other media contain these components at lower levels. Especially, considering that the difference between LS and MS media is only vitamin-sourced and the better germination performance in MS than LS medium, it can be concluded that the vitamin composition of culture medium plays a vital role in the seed germination of $P$. pratensis. On the other hand, faster seed germination in $P$. pratensis after priming the seeds with $\mathrm{KNO}_{3}$ solution has been reported by Pill and Korengel (1997). Ervin et al., (2017) stated that ammonium tends to be oxidized in time and leads to the decreased availability of $\mathrm{P}$ for plants following soil acidification that is an unfavorable condition for bluegrass. The same researchers also concluded that without using $\mathrm{P}$ - or K-containing fertilizers, only sulfates of ammonium and Fe reduce the growth and spread of P. annua (Ervin et al., 2017). Therefore, the better seed germination performance of $\mathrm{SH}$ and DG than MS and LS media might be explained by their lesser $\mathrm{NH}_{4}$ but higher $\mathrm{P}$ contents. Furthermore, ammonium phosphate may increase nutrient availability with a lesser salt effect. In this context, $\mathrm{NH}_{4} \mathrm{H}_{2} \mathrm{PO}_{4}$ has been previously shown to induce nutrient availability in Hypericum $\times$ moserianum (Pizzeghello et al., 2019).

Mean leaf numbers developed from per seed are shown in Figure 3. The highest number of leaves $(2.12 \pm 0.18)$ was found in the DG medium, whereas LS medium gave the lowest $(1.13 \pm 0.04)$ result. MS and LS media gave statistically the same results, while the same statistical result was found between $\mathrm{SH}$ and DG media. Therefore, the DG and SH media were found better for leaf development than the other media tested. A similar trend with mean leaf numbers was also found in the mean leaf lengths (Fig. 4). SH and DG media gave statistically the same results, while the same statistical relationship was found between MS and LS media. The most elongated leaves $(4.28 \pm 0.28 \mathrm{~cm})$ were measured from the plants developed on $\mathrm{SH}$ medium, while LS medium gave the lowest $(2.32 \pm 0.26 \mathrm{~cm})$ mean leaf lengths. Therefore, better leaf elongation performance in $P$. pratensis was found in the $\mathrm{SH}$ and DG media than the other media tested. In addition to the above-discussed differences among macroelement compositions of the media tested, the LS medium's drawback in supplying leaf growth for $P$. pratensis may be due to the lack of vitamins such as pyridoxine and nicotinic acid in its formulation. The exogenously provided non-phosphorylated $\mathrm{B}_{6}$ vitamers have been shown to reduce singlet oxygen accumulation in plants (Vanderschuren et al., 2013). Also, Colinas et al. (2016) showed that balancing $B_{6}$ vitamers is vital for the metabolism and plant development in Arabidopsis. Vitamin $B$ has many beneficial roles in plants, such as activation of plant disease resistance (Ahn et al., 2005), alleviating the effects of several environmental stresses, and regulating post-embryonic root development (Chen \& Xiong, 2005) since they are cofactors required by numerous enzymes. For instance, nicotinic acid has been found to alleviate the effects of salt stress in Allium cepa (Ali, 2002) and Ricinus communis (Hussein et al., 2014). Although LS medium includes thiamine (vitamin $B_{1}$ ) as vitamin $B$, it seems that the lack of nicotinic acid (vitamin $B_{3}$ ) and pyridoxine (vitamin $\mathrm{B}_{6}$ ) is the main disadvantage of LS medium in comparison with other media tested in this study.

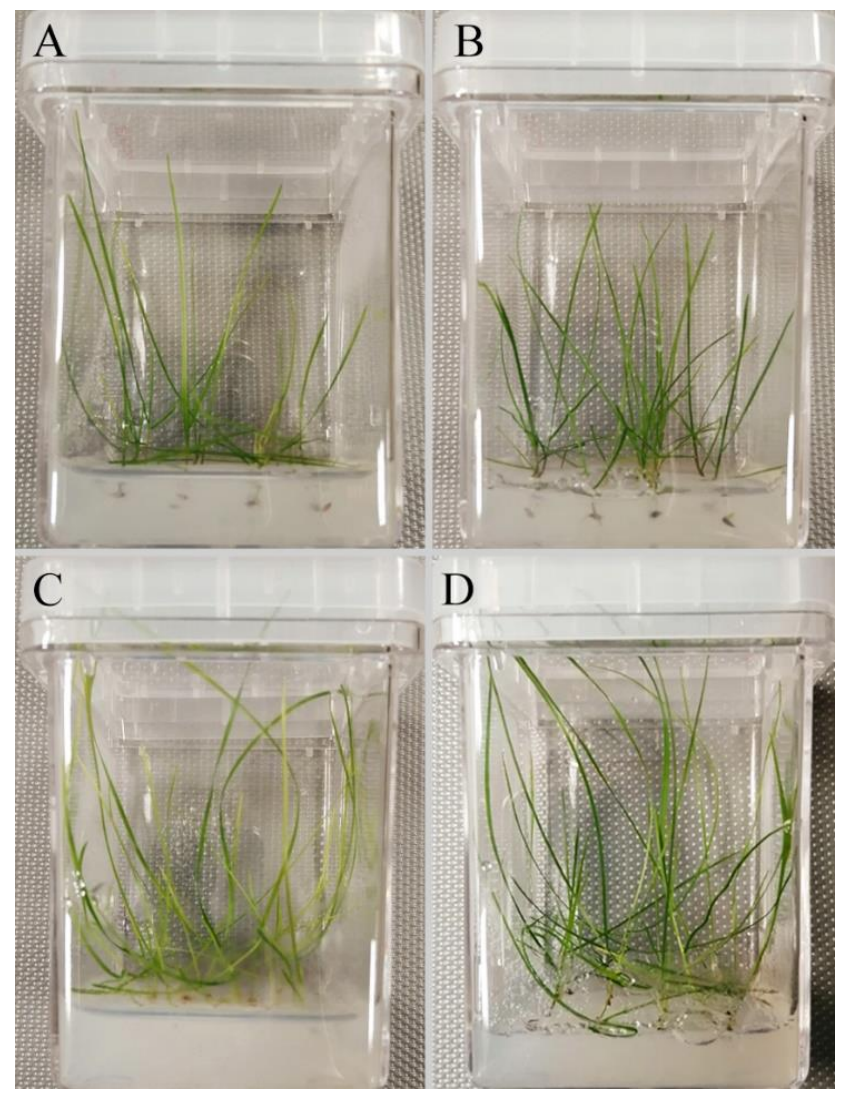

Figure 1. The appearance of the cultures at the end of the incubation period. Seeds germinated in LS (A), MS (B), DG (C), and SH media (D).

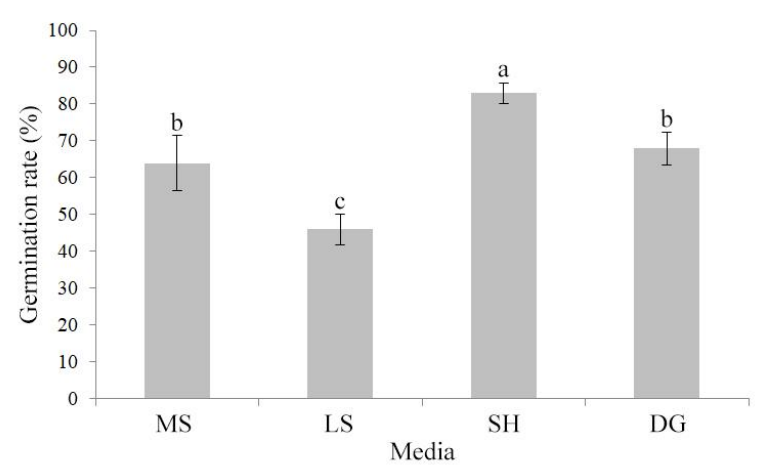

Figure 2. Effect of culture medium on in vitro germination of $P$. pratensis seeds. Data represent mean \pm SD. The bars with the same superscript letters are not significantly different by Duncan's multiple range test $(P<0.05)$.

The root development performance of $P$. pratensis in the media tested is shown in Fig. 5. The highest number of roots $(3.09 \pm 0.26)$ was found in the $\mathrm{SH}$ medium, whereas the LS medium gave the lowest $(1.84 \pm 0.1)$ mean root 
number. MS and DG media gave statistically the same results. The root elongation was found better in the $\mathrm{SH}$ medium than the other media tested (Fig. 6). However, MS and LS media gave statistically the same results. The longest roots $(1.43 \pm 0.19 \mathrm{~cm})$ were measured from the plants developed on SH medium, while DG medium gave the lowest $(0.81 \pm 0.08 \mathrm{~cm})$ mean root lengths. These results suggested that $\mathrm{SH}$ medium better induces the rhizogenesis in $P$. pratensis than the other media tested. The turfgrass roots can release phytosiderophores under Fe- or Zndeficient conditions that serve as natural chelating agents to extract micronutrients such as iron manganese, copper, and zinc from the soil (Ueno et al., 2007). However, a significant portion of the differentiation among the media's effects might come mostly from the macroelement and vitamin compositions since they cover relatively more space in a medium's formulation than microelements. Nevertheless, it should be noted that some microelements such as molybdenum (Mo) and zinc ( $\mathrm{Zn}$ ) are required for the biosynthesis of abscisic acid and indole-3 butyric acid that modulate the growth of primary and lateral roots (Kaiser et al., 2005). Furthermore, the role of another microelement, cobalt, in lateral root formation has been demonstrated in Oryza sativa (Hsu et al., 2013). Therefore, even microelements are required in low concentration, the disadvantage of DG medium in root elongation might stem from its minimal $\mathrm{Mo}$ and Co content. Another significant difference among the media tested is their myoinositol contents. SH medium has the highest amount of myo-inositol that is ten times higher than those of the other media tested. Myo-inositol plays a significant role in many biosynthetic pathways of stress-molecule production and cell wall formation in plants (Loewus \& Murthy, 2000). Also, it takes part in phosphate storage, cell communication, and transportation of plant hormones (Luo et al., 2011). In a tissue culture study, myo-inositol has been found to enhance the shoot growth and root development in the Malus domestica and Pyrus communis explants. The authors stated that higher levels of myoinositol could be required to improve the explants' morphogenetic ability (Toma et al., 2012).

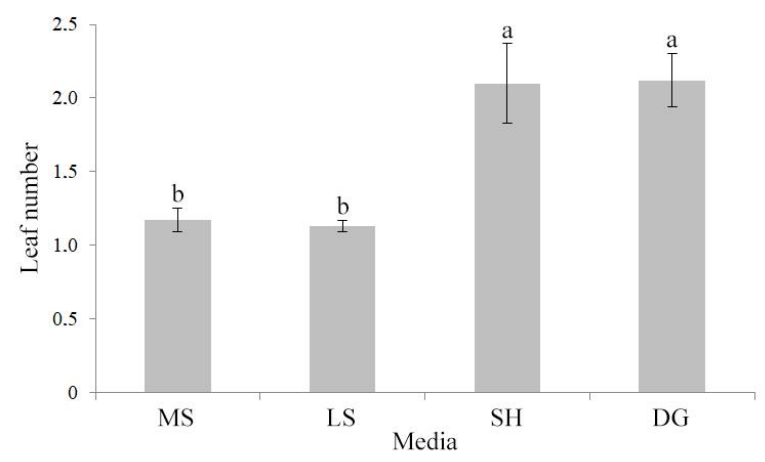

Figure 3. Effect of culture medium on in vitro leaf production in $P$. pratensis. Data represent mean $\pm \mathrm{SD}$. The bars with the same superscript letters are not significantly different by Duncan's multiple range test $(P<0.05)$.

The developmental data-based hierarchical clustering heatmap shows the relationship among the media tested (Fig. 7). All the media tested were grouped into two main clusters. SH and DG media were found in the same cluster, while MS and LS media were placed in another cluster suggesting that the media's effects in the same cluster were more similar than the other media. The normalized data having the red color better developmental results in $P$. pratensis, while the data represented by blue color shows the lower developmental performance.

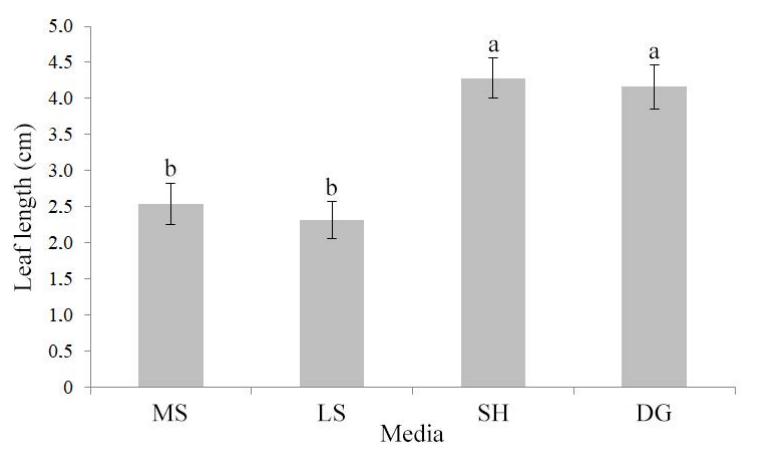

Figure 4. Effect of culture medium on in vitro leaf elongation in $P$. pratensis. Data represent mean $\pm \mathrm{SD}$. The bars with the same superscript letters are not significantly different by Duncan's multiple range test $(P<0.05)$.

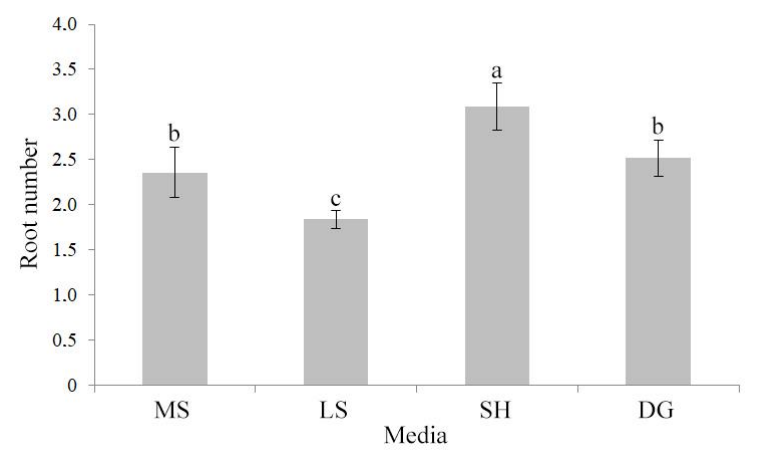

Figure 5. Effect of culture medium on in vitro root production in $P$. pratensis. Data represent mean \pm SD. The bars with the same superscript letters are not significantly different by Duncan's multiple range test $(P<0.05)$.

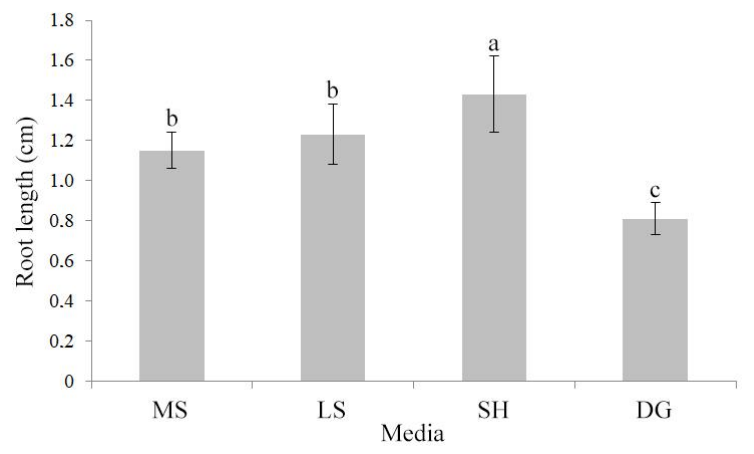

Figure 6. Effect of culture medium on in vitro root elongation in $P$. pratensis. Data represent mean $\pm \mathrm{SD}$. The bars with the same superscript letters are not significantly different by Duncan's multiple range test $(P<0.05)$.

\section{Conclusion}

In the present study, influences of different culture media on in vitro seed germination and plant development in $P$. pratensis L. were evaluated based on the developmental parameters. In conclusion, $\mathrm{SH}$ media should be preferred 
over the other medium to achieve a higher seed germination rate and better plant development in $P$. pratensis. The findings of this study would contribute to the improvement studies on the forage and grass species. Also, the effects of growth promoters should be tested to increase the efficiency of the medium.

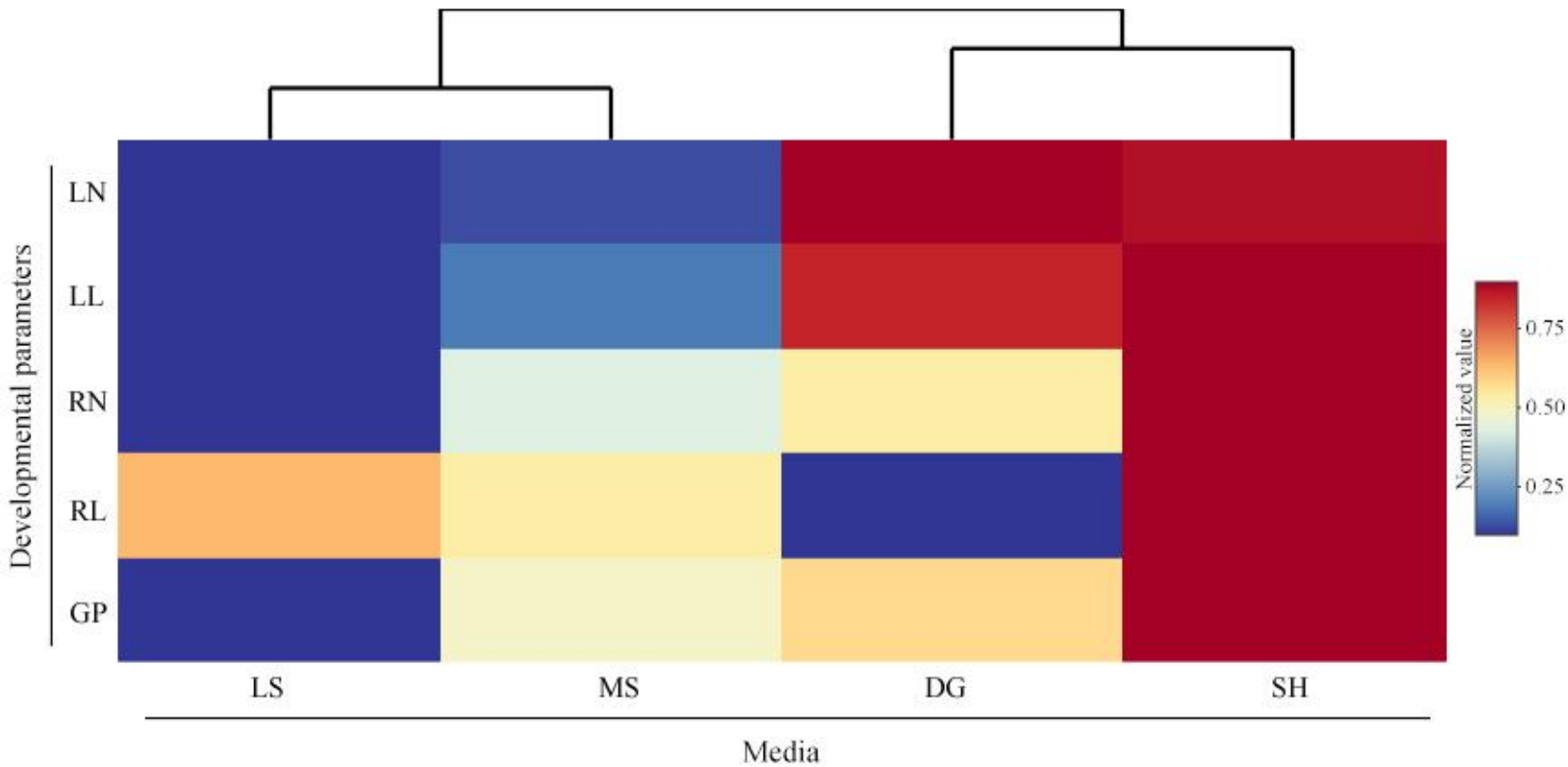

Figure 7. Hierarchical clustering heatmap-based comparison of the developmental data. Leaf number (LN), Leaf length (LL), Root number $(\mathrm{RN})$, Root length (RL), Germination percentage (GP)

Acknowledgements: The author would like to thank Duhan Trrlı and Serdar Yildiz for their help with the inoculation process of the cultures used in this paper.

Ethics committee approval: Ethics committee approval is not required for this study.

Conflict of interest: The author declares that there is no conflict of interest.

\section{References}

Acemi, A., \& Özen, F. (2019). Optimization of in vitro asymbiotic seed germination protocol for Serapias vomeracea. The EuroBiotech Journal, 3(3), 143-151. https://doi.org/10.2478/ebtj-2019-0017

Acemi, A., Bayrak, B., Çakır, M., Demiryürek, E., Gün, E., El Gueddari, N. E., \& Özen, F. (2018). Comparative analysis of the effects of chitosan and common plant growth regulators on in vitro propagation of Ipomoea purpurea (L.) Roth from nodal explants. In Vitro Cellular \& Developmental Biology - Plant, 54(5), 537-544. https://doi.org/10.1007/s11627-0189915-0

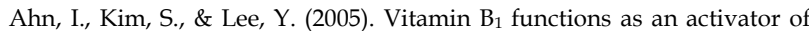
plant disease resistance. Plant Physiology, 138(3), 1505-1515. https://doi.org/10.1104/pp.104.058693

Akdeniz, H., Hosaflığlu, İ., \& Keskin, B. (2018). Impact of different sowing rates and cutting times on quality properties of Kentucky Bluegrass (Poa pratensis L. cv. Geronimo). Iğdır University Journal of the Institute of Science and Technology, 8(1), 301-308. https://doi.org/10.21597/jist.407889

Ali, R.M. (2002). Effect of nicotinic acid and nicotinamide adenine dinucleotide on growth and content of oil, glycerol and ricinine alkaloids of salinity stressed Ricinus communis L. Phyton (Horn, Austria), 42(2), 269-277.

Benvenuti, S., \& Mazzoncini, M. (2018). Soil physics involvement in the germination ecology of buried weed seeds. Plants, 8(1), 7 . https:// doi.org/10.3390/plants8010007

Borawska-Jarmułowicz, B., Mastalerczuk, G., Gozdowski, D., Małuszyńska, E., \& Szydłowska, A. (2017). The sensitivity of Lolium perenne and Poa pratensis to salinity and drought during the seed germination and under different photoperiod conditions. ZemdirbysteAgriculture, 104(1), 71-78. https:/ / doi.org/10.13080/z-a.2017.104.010

Bush, T. (2002). USDA NRCS Plant Fact Sheet - Kentucky Bluegrass Poa pratensis $\quad$ L. $\quad$ Retrieved from https://plants.usda.gov/factsheet/pdf/fs_popr.pdf
Casler, M.D. (2006). Perennial grasses for turf, sport and amenity uses: Evolution of form, function and fitness for human benefit. Journal of Agricultural Science, 144(3), 189-203. https://doi.org/10.1017/S0021859606006137

Chen, H., \& Xiong, L. (2005). Pyridoxine is required for post-embryonic root development and tolerance to osmotic and oxidative stresses. The Plant Journal, 44(3), 396-408. https://doi.org/10.1111/j.1365313x.2005.02538.x

Colinas, M., Eisenhut, M., Tohge, T., Pesquera, M., Fernie, A.R., Weber, A.P., \& Fitzpatrick, T.B. (2016). Balancing of $B_{6}$ vitamers is essential for plant development and metabolism in Arabidopsis. The Plant Cell, 28(2), 439-453. https://doi.org/10.1105/tpc.15.01033

De Greef, W., \& Jacobs, M. (1979). In vitro culture of the sugarbeet: Description of a cell line with high regeneration capacity. Plant Science Letters, 17(1), 55-61. https:// doi.org/10.1016/0304-4211(79)90109-3

Ervin, E.H., Reams, N., Zhang, X., Boyd, A., \& Askew, S. (2017). An integrated nutritional and chemical approach to Poa annua suppression in creeping Bentgrass Greens. Crop Science, 57(2), 567-572. https://doi.org/10.2135/cropsci2016.05.0308

Esmaeili, S., Salehi, H., \& Khosh-Khui, M. (2018). Direct and indirect in vitro plant regeneration of two commercial cultivars of perennial ryegrass. Advances in Horticultural Science, 32(2), 273-280. https://doi.org/10.13128/ahs-20654

Giolo, M., Dalla Montà, A., Barolo, E., Ferrari, F., Masin, R., \& Macolino, S (2017). High-temperature effects on seed germination of fourteen Kentucky bluegrass (Poa pratensis L.) cultivars. Agronomy Research, 15(1), 123-132.

Hsu, Y.Y., Chao, Y., \& Kao, C.H. (2013). Cobalt chloride-induced lateral root formation in rice: The role of heme oxygenase. Journal of Plant Physiology, 170(12) https://doi.org/10.1016/i.jplph.2013.03.004

Hussein, M.M., Faham, S.Y., \& Alva, A.K. (2014). Role of foliar application of nicotinic acid and tryptophan on onion plants response to salinity stress. Journal of Agricultural Science, 6(8), 41-51. https://doi.org/10.5539/jas.v6n8p41

Kaiser, B.N., Gridley, K.L., Ngaire Brady, J., Phillips, T., \& Tyerman, S.D. (2005). The role of molybdenum in agricultural plant production. Annals of Botany, 96(5), 745-754. https://doi.org/10.1093/aob/mci226

Linsmaier, E.M., \& Skoog, F. (1965). Organic growth factor requirements of tobacco tissue cultures. Physiologia Plantarum, 18(1), 100-127. https://doi.org/10.1111/j.1399-3054.1965.tb06874.x

Loewus, F.A., \& Murthy, P.P. (2000). Myo-inositol metabolism in plants. Plant Science, 150(1), 1-19. https://doi.org/10.1016/s0168$\underline{9452(99) 00150-8}$ 
Luo, Y., Qin, G., Zhang, J., Liang, Y., Song, Y., Zhao, ......,\& Qu, L. (2011). D-myo-Inositol-3-Phosphate affects phosphatidylinositol-mediated endomembrane function in Arabidopsis and is essential for auxinregulated embryogenesis. The Plant Cell, 23(4), 1352-1372. https://doi.org/10.1105/tpc.111.083337

Murashige, T., \& Skoog, F. (1962). A revised medium for rapid growth and bio assays with tobacco tissue cultures. Physiologia Plantarum, 15(3), 473-497. https://doi.org/10.1111/j.1399-3054.1962.tb08052.x

Pill, W.G., \& Korengel, T.K. (1997). Seed priming advances the germination of Kentucky Bluegrass (Poa pratensis L.). Journal of Turfgrass Management, 2(1), 27-43. https://doi.org/10.1300/j099v02n01_03

Pizzeghello, D., Schiavon, M., Maretto, L., Stevanato, P., Ertani, A., Altissimo, A., \& Nardi, S. (2019). Short-term application of polymercoated mono-ammonium phosphate in a calcareous soil affects the pools of available phosphorus and the growth of Hypericum $\times$ moserianum (L.). Frontiers in Sustainable Food Systems, 3. https://doi.org/10.3389/fsufs.2019.00004

Schenk, R.U., \& Hildebrandt, A.C. (1972). Medium and techniques for induction and growth of monocotyledonous and dicotyledonous plant cell cultures. Canadian Journal of Botany, 50(1), 199-204. https://doi.org/10.1139/b72-026

Toma, R.S., Danial, G.N., \& Habash, A.H. (2012). In vitro morphogenetic response of Apple (Malus domestica Borkh.) and pear (Pyrus communis L.) to the elevated levels of copper and myo-inositol. Acta Agrobotanica, 65(3), 43-48. https://doi.org/10.5586/aa.2012.005

Ueno, D., Rombolà, A.D., Iwashita, T., Nomoto, K., \& Ma, J.F. (2007). Identification of two novel phytosiderophores secreted by perennial grasses. New Phytologist, 174(2), 304-310. https://doi.org/10.1111/j.1469-8137.2007.02056.x

Vanderschuren, H., Boycheva, S., Li, K., Szydlowski, N., Gruissem, W., \& Fitzpatrick, T.B. (2013). Strategies for vitamin $B_{6}$ biofortification of plants: A dual role as a micronutrient and a stress protectant. Frontiers in Plant Science, 4. https:// doi.org/10.3389/fpls.2013.00143

Walker, K.S., Bigelow, C.A., Smith, D.R., Van Scoyoc, G.E., \& Reicher, Z.J. (2007). Aboveground responses of cool-season lawn species to nitrogen rates and application timings. Crop Science, 47(3), 1225-1236. https://doi.org/10.2135/cropsci2006.09.0595 